\title{
LITHOLOGICAL FEATURES OF THE SEDIMENTS THAT COVER THE COAL-BEARING FORMATION IN THE LVIV-VOLYN BASIN AND THEIR INFLUENCE OVER COAL MINING CONDITIONS \\ Y. Stepanenko1, V. Shulga²
}

\author{
ЛИТОЛОГИЧЕСКИЕ ОСОБЕННОСТИ ОТЛОЖЕНИЙ, ПОКРЫВАЮЩИХ УГЛЕНОСНУЮ \\ ФОРМАЦИЮ ЛЬВОВСКО-ВОЛЫНСКОГО БАССЕЙНА, И ИХ ВЛИЯНИЕ \\ НА УСЛОВИЯ РАЗРАБОТКИ ПЛАСТОВ УГЛЯ \\ Я. Степаненко1, В. Шульга²
}

Eight lithological sequences are recognized among the Mesozoic sediments that cover the Carboniferous coal-bearing formation. Those are (upward): terrigenous, terrigenous-carbonate, Upper Jurassic carbonate, lower sand, upper sand, limestone, lower marl, and upper marl of the Upper Cretaceous. The terrigenous Jurassic and sand Lower Cretaceous sequences influenced most negatively the conditions of coal mining. The basin has been zoned on the influence of Mesozoic sediments over geological and mining conditions of coal recovery.

Key words: Lethological features, coal-bearing formation, coal recovery, mining conditions, Lviv-Volyn Basin.

Среди мезозойских отложений, покрывающих угленосную формацию карбона, выделяются восемь литологических толщ (снизу вверх): терригенная, терригенно-карбонатная, карбонатная верхней юры, песчаная нижняя , песчаная верхняя, известняковая, мергельная нижняя, мергельная верхняя верхнего мела. На условия разработки угольных пластов наибольшее отрицательное влияние оказывают терригенная толща юры и песчаная нижняя мела. Проведено районирование территории бассейна по степени влияния мезозойских отложений на горно-геологические условия эксплуатации месторождений угля.

Ключевые слова: литологические особенности, угленосная формация, месторождения угля, условия разработки, Львовско-Волынский бассейн.

\section{ВВЕДЕНИЕ}

Львовско-Волынский бассейн (ЛВБ) относится к типу закрытых угольных бассейнов. На всей его территории карбоновая угленосная формация покрыта породами мезозоя, оказывающими отрицательное влияние на геологоразведочные и горно-эксплуатационные работы. Это влияние имеет разный характер и в значительной степени зависит от литологических особенностей пород, залегающих на угленосной толще. Отдельные аспекты указанной проблемы нашли отражение в ряде публикаций $[1,2]$. В то же время появление в последние годы обширного нового фактического материала определяет необходимость еще раз рассмотреть вопрос о литологических особенностях мезозойских отложений, а также о степени их влияния на освоение промышленностью угольных месторождений бассейна.

\section{ОБЩИЕ СВЕДЕНИЯ О БАССЕЙНЕ}

ЛВБ - это площадь развития угленосных отложений с пластами углей нижнего (турнейский, визейский и серпуховский ярусы) и среднего (башкирский ярус) карбона, расположенная на крайнем западе Украины в верхнем течении р. Буг. Область распространения угленосного карбона простирается в северо-западном направлении от городов Львов, Перемышляны на юге до государственной границы с республикой Беларусь на севере на расстояние более 200 км при ширине до 80 км. Общая площадь ЛВБ превышает 5000 км², а территории с промышленной угленосностью - около 1000 км². ЛВБ является юго-восточным продолжением Люблинского угольного бассейна, расположенного на территории Польши. Угленосная толща ЛВБ имеет мощность до 1500 м и слагается переслаивающимися между собой песчаниками, алевролитами, аргиллитами, известняками и углями. Из более чем 90 угольных пластов и прослоев в бассейне разрабатываются шесть пластов, развитых в бужанской свите, расположенной в верхней части угленосного разреза.

В пределах ЛВБ с севера на юг выделяются Нововолынский (Волынское месторождение), Червоноградский (Забугское, Межреченское месторождения) геолого-промышленные районы, а также Юго-Западный угленосный район (Тягловское и Любельское месторождения) (см. рисунок). В насто- 
ящее время в бассейне действуют 14 шахт, разрабатывающих угольные пласты Волынского (четыре шахты) и Межреченского (10 шахт) месторождений. Одна шахта (№ 10 Нововолынская) находится в строительстве на Волынском месторождении. Два участка (№ 3 и 4 Червоноградские), расположенные на Забугском месторождении, и три участка (№ 1 Тягловский, № 1 и 2 Любельские), находящиеся соответственно на Тягловском и Любельском месторождениях, подготовлены для строительства новых шахт. Наибольшие перспективы развития угольной промышленности ЛВБ связаны с освоением месторождений Юго-Западного угленосного района.

\section{ЛИТОЛОГИЧЕСКИЕ ОСОБЕННОСТИ МЕЗОЗОЙСКИХ ОТЛОЖЕНИЙ}

Образования мезозоя залегают на угленосных отложениях карбона с большим размывом. В нижней части разреза располагаются отложения оксфордского, кимериджского и титонского ярусов верхней юры. По литологическому составу они подразделяются на три толщи (снизу вверх): терригенную, терригенно-карбонатную и карбонатную (см. таблицу).

Терригенная толща представлена пестроцветными разнозернистыми песчаниками, алевролитами, аргиллитами, глинами, реже - гравелитами и конгломератами. В ее верхней части расположены пропластки, линзы, включения ангидритов и доломитов, а в нижней - локально развитые сероцветные пески и глины с обугленными растительными остатками. Песчаники и алевролиты составляют 45-55\% объема толщи и в основном равномерно распределяются в разрезе и по площади. Это также характерно для аргиллитов, преимущественно слагающих верхнюю часть толщи и составляющих 30-50\% объема разреза. Гравелиты и конгломераты характеризуются неравномерным развитием по площади и в основном приурочены к нижней части толщи. Наряду с площадями, где они полностью отсутствуют или их содержание не превышает 5-10\%, располагаются участки, в пределах которых гравелиты и конгломераты составляет 20-50 и даже 60-70\% разреза толщи. Как показали детальные исследования, проведенные на Любельском месторождении, площади распространения гравелитов и конгломератов имеют северо-западное простирание. Их размер по площади, а также относительное содержание в разрезе грубообломочных образований вначале увеличиваются к юго-западу в направлении возрастания общей мощности терригенной толщи, а затем уменьшаются. Терригенные отложения в основном распространены на Любельском месторождении в пределах Юго-Западного угленосного района. В общем их мощность возрастает от 10-30 м на северо-востоке района до 80-100 м на юго-западе и юге.

Терригенно-карбонатная толща, по сравнению с терригенной, имеет более ограниченное развитие и распространена на юге ЛВБ. В нижней части она представлена пестроцветными песчаниками, аргиллитами и глинами, а в верхней (на 60-80 \%) - доломитами, доломитизированными известняками и ангидритами с пластами и пропластками известняков. Очень часто в терригенно-карбонатной толще встречаются линзы и включения гипсов и темно-серых глин. Мощность толщи увеличивается в юго-западном направлении от 10-30 м на северо-востоке Юго-Западного района до 100-110 м на юго-западе.

Карбонатная толща, как и предыдущие, находится в юго-западной части указанного района. Она имеет довольно однообразный состав. Это - светло-серые, белые известняки, местами мелоподобные. В нижней части толщи иногда встречаются слои и прослои доломитизированных известняков. Мощность толщи увеличивается от 10-30 м на северо-востоке Юго-Западного района до 80-100 м на юго-западе.

Расположенные выше отложения верхнего мела развиты на всей территории ЛВБ и относятся к сеноманскому, туронскому ярусам и сенонскому надъярусу (см. таблицу). Их мощность увеличивается к юго-западу и достигает 800 м. Сеноманские отложения представлены горизонтом песчаников, который в пределах Юго-Западного района распространен повсеместно. По литологическому составу он подразделяется на две толщи. Нижняя песчаная толща (мощностью 1,1-4,5 м) состоит из зеленовато-серых среднезернистых кварц-глауконитовых песчаников, в нижней части которых содержится галька фосфоритов и кремнисто-глинистых пород. Верхняя песчаная толща (мощностью 4,5-19 м) слагается серыми мелкозернистыми кварцевыми песчаниками. Общая мощность сеноманских отложений увеличивается к юго-западу от 4-7 м на северо-востоке Юго-Западного района до 20-25 м на юго-западе. 
Выше залегает известняковая толща турона. Она представлена белыми, светло-серыми известняками, кремнистыми, сильно кремнистыми в нижней части толщи и глинисто-кремнистыми в верхней. Степень окремнения известняков увеличивается сверху вниз. Мощность туронских отложений возрастает от 110 м на северо-востоке бассейна до 190 м на юго-западе.

Образования сенонского надъяруса представлены светло-серыми мергелями. По степени их влияния на горно-геологические условия выделяются две толщи: мергельная нижняя и мергельная верхняя. Для первой характерны слабая трещиноватость и малая обводненность пород. Вторая отличается повышенной и интенсивной трещиноватостью мергелей, а также их сильной обводненностью. Мощность мергельных толщ сенона увеличивается в юго-западном направлении от 370 м на северо-востоке до 780 м - на юго-западе.

\section{ВЛИЯНИЕ ПОКРЫВАЮЩИХ ПОРОД НА УСЛОВИЯ РАЗРАБОТКИ И РАЙОНИРОВАНИЕ ТЕРРИТОРИИ ЛВБ}

В таблице приведены данные о характере проявления осложнений горно-геологических условий при вскрытии угольных месторождений, разработке угольных пластов, а также степени их влияния на горно-геологические условия. В этом отношении наиболее простыми условиями для проведения горных работ (1-я степень влияния) характеризуются отложения карбонатной толщи верхней юры, а также известняковая и мергельная нижняя толщи верхнего мела. Значительное усложнение горногеологических условий (увеличение водопритоков, выносы песка - 2-я степень влияния) связано с отложениями терригенно-карбонатной толщи верхней юры, песчаной верхней и мергельной верхней толщами верхнего мела. Наибольшее отрицательное влияние литологического состава покрывающих отложений на проходку стволов, подготовительных и очистных подземных горных выработок (3я степень влияния) будет проявляться в породах верхнеюрской терригенной толщи, а также песчаной нижней толщи верхнего мела. При этом усложнения отличаются разнообразным характером: увеличение водопритоков, выносы песка и плывуна, обрушения при проходке стволов и в подземных горных выработках при разработке угольных пластов вблизи выхода их под покрывающие терригенные отложения верхней юры.

Изложенные результаты проведенного исследования, а также установление особенностей площадного распространения выделенных литологических толщ, явились основой для последующего районирования территории ЛВБ. Выделяются три типа площадей и участков, характеризующихся слабым (I тип), средним (II тип) и сильным (III тип) влиянием мезозойских отложений на условия разработки угольных месторождений (см. рисунок). К I типу относятся площади распространения меловых отложений небольшей мощности (300-400 м) при полном отсутствии юрских образований. Известняковая толща турона и нижняя мергельная толща нижнего сенона являются мощным водоупором, разделяющим основной верхнесенонский и нижележащие водоносные горизонты. В связи с этим указанные горизонты не окажут существенного влияния на ведение горно-эксплуатационных работ на новых шахтах бассейна. Однако при проектировании и строительстве угледобывающих предприятий следует учитывать уменьшение прочности и увеличение водопроводности водоупорной толщи меловых отложений вследствие сдвига пород над подземными горными выработками. Это подтверждается результатом анализа баланса формирования общешахтных водопритоков действующих предприятий. При проходке новых стволов на глубинах 20-90 м возможны осложнения, связанные с трещиноватыми и водообильными мергелями сенонского надъяруса. Резкое увеличение притоков воды и выносы песка возможны в местах непосредственного залегания на угленосных отложениях карбона сеноманских песчаников. В общем, область / типа характеризуется наименьшей степенью отрицательного влияния покрывающих угленосные отложения мезозойских пород на условия разработки угольных месторождений. Она занимает большую часть (до 80 \%) территории Нововолынского и Червоноградского районов, а также северо-восточную часть (до 40\%) Юго-Западного района. В пределах области I типа находится большинство действующих шахт и разведанных участков.

Ко // типу относятся площади и отдельные участки развития маломощных (5-28 м) юрских отложений, представленных в основном отложениями нижней (терригенной) толщи. При непосредственном контакте с угольными пластами или нахождении в непосредственной близости от них (до 2-4 м) юрские отложения приобретают свойства текучести, что приводит к непредвиденным осложнениям горных работ (обвалы, выносы песка и плывуна, увеличение водопритоков и др.). Участки ІІ-го типа 
имеют локальное распространение в пределах эксплуатируемой части бассейна. При этом горные работы проводились только на отдельных участках, расположенных в пределах шахтных полей. В связи с этим влияние мезозойских отложений на проходку стволов и проведение горных работ не имело существенного значения. В пределах перспективного для развития угольной промышленности Юго-Западного района участки // типа занимают сравнительно небольшую площадь на северо-западе Тягловского месторождения.

III тип площадей характеризуется повышенной мощностью меловых отложений, большой площадью распространения, значительной мощностью, а также полнотой разреза юрских отложений. Такая площадь распространена только на юге ЛВБ, полностью охватывая территорию Любельского месторождения (см. рисунок). На большей площади Юго-Западного района юрские отложения образуют сплошной полого залегающий покров мощностью от 40-50 до 170-230 м, с которым будут связаны основные явления, отрицательно влияющие на проведение горно-эксплуатационных работ. Из трех выделенных толщ верхней юры наиболее опасной для разработки угольных месторождений является самая нижняя (терригенная). Слагающие ее глины, аргиллиты, алевролиты, песчаники в основном рыхлые, слабо- и среднесцементированные. Они характеризуются наиболее низкими физико-механическими оказателями ( $f=1$ - 3) и относительно повышенными водообильностью и водопроводностью $\left(\mathrm{Q}=40-120 \mathrm{M}^{3} ; \mathrm{K}_{\mathrm{m}}=0,2-0,9 \mathrm{~m}^{2} /\right.$ сут). По аналогии с освоенными промышленностью площадями // типа, в пределах которых развиты отложения нижней (терригенной) толщи, а также принимая во внимание морфологические условия залегания угольных пластов, сравнительно большую глубину залегания и мощность терригенной толщи верхней юры, с большой достоверностью можно ожидать значительное отрицательное их влияние на разработку Любельского и в меньшей степени - Тягловского месторождений.

Меньшее, но также значительное негативное влияние на горно-эксплуатационные работы, следует связывать с отложениями средней терригенно-карбонатной толщи. Наибольшую опасность они будут представлять при освоении промышленностью полей шахт № 1 - 5 Любельских, где отложения этой толщи имеют весьма широкое распространение. На основании гидрогеологических наблюдений, изучения физико-механических свойств пород, проведенных в южной части Любельского месторождения (участки № 1, 2), можно утверждать, что в общем породы средней толщи юры (песчаники, доломиты, известняки, ангидриты, глины) характеризуются средними (в верхней части толщи) и низкими (в нижней ее части) физико-механическими показателями, а также слабо обводнены. Однако из-за частого переслаивания монолитных, крепких, плотных доломитов, известняков, ангидритов с рыхлыми и слабо сцементированными глинами, аргиллитами, глинистыми песчаниками и алевролитами, при работе будущих шахт зона влияния горных работ (зона водопроводных трещин) будет наблюдаться по всей мощности терригенной толщи и в отдельных случаях, вероятно, достигать отложений и терригенно-карбонатной. В таких случаях поступление воды в шахты будет происходить из двух указанных толщ и будет зависеть от мощности и интенсивности развития зон трещиноватости. Прохождение стволов в терригенно-карбонатной толще будет связано также с неблагоприятными условиями, особенно в нижней ее части, где часто встречаются прослойки глин и глинистых песчаников, которые при обводнении приобретают свойства плывунов и вызовут обрушения.

Инженерно-гидрогеологическими исследованиями, проведенными в южной части Любельского месторождения, установлено, что водообильность и водопроводность пород верхнеюрской карбонатной толщи преимущественно очень низкие. В общем, ее можно охарактеризовать как относительно безводную, которая разделяет вышележащие рыхлые водонасыщенные сеноманские отложения и нижележащие образования терригенно-карбонатной и терригенной толщ.

\section{ЗАКЛЮЧЕНИЕ}

С учетом новейших данных на всей территории ЛВБ проанализировано негативное влияние покрывающих угленосную толщу образований мезозоя на условия разработки угольных месторождений. Это влияние имеет разный характер и в значительной степени определяется особенностями литологического состава мезозойских отложений.

В вертикальном разрезе покрывающих отложений выделено восемь литологических толщ, поразному усложняющих горно-геологические условия. Наиболее неблагоприятные условия эксплуатации угольных месторождений связаны с терригенной толщей верхней юры. 
Осуществлено районирование территории бассейна с выделением трех типов площадей и участков, характеризующихся слабым (I тип), средним (II тип) и сильным (III тип) влиянием мезозойских отложений на условия разработки угольных месторождений. Основная часть территории бассейна, расположенная в центральной и северной ее частях, отнесена к I и // типам. Наиболее значительное отрицательное влияние мезозойских отложений проявляется в Юго-Западном угленосном районе (III тип).

Изложенные материалы представляют интерес для широкого круга специалистов, осуществляющих разведку угольных месторождений, а также проектирование и строительство

угледобывающих предприятий. Особую значимость они имеют для оценки горно-геологических условий перспективного Юго-Западного района, в пределах которого промышленное освоение месторождений угля только начинается.

\section{Схема районирования территории ЛВБ по степени влияния мезозойских отложений на условия разработки угольных месторождений}

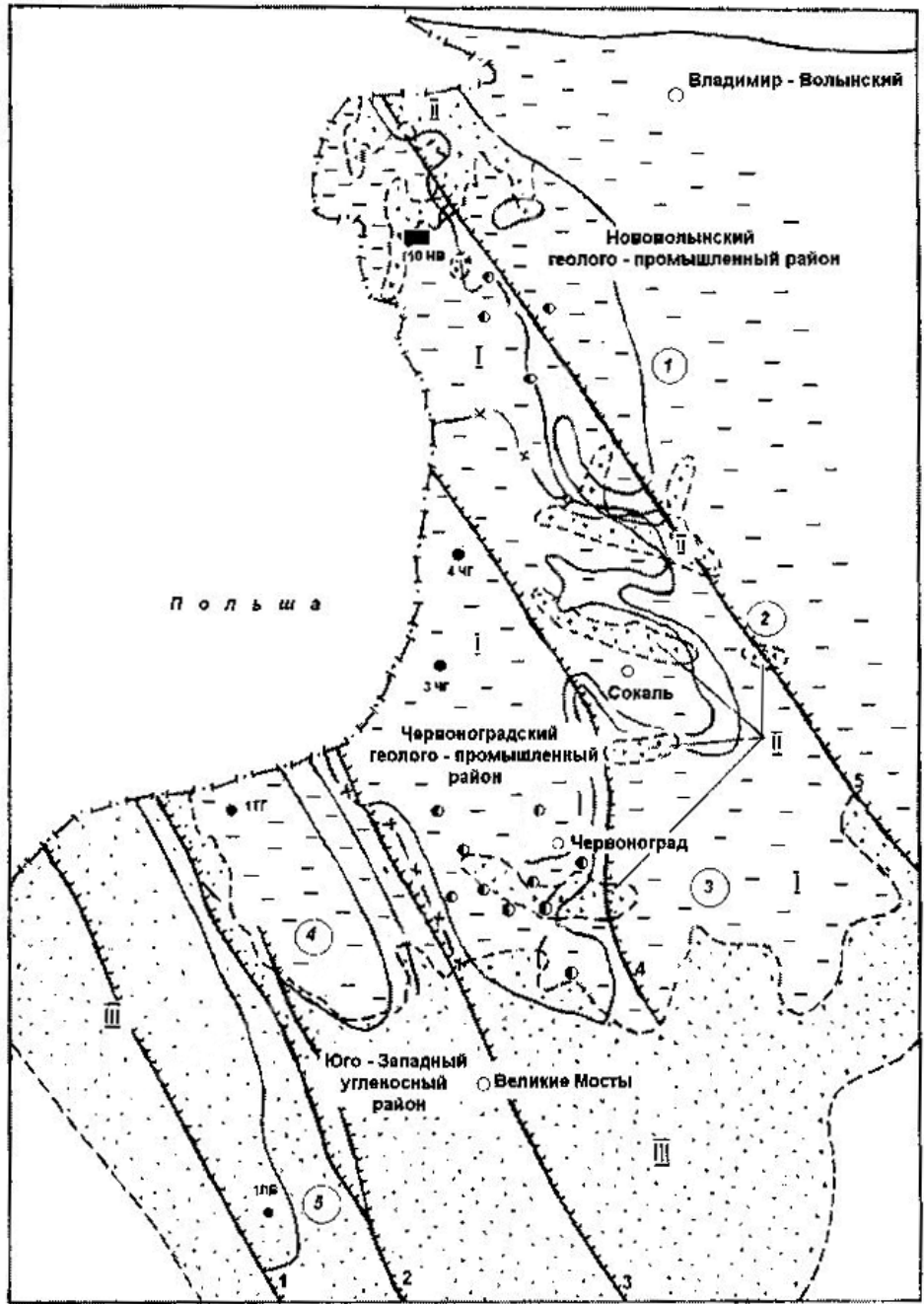

Площади и участки влияния мезозойских отложений на условия разработки: 1 - слабого, 2 - среднего, 3 - сильного; 4 границы площадей влияния мезозойских отложений; 5 контур промышленной угленосности; 6 - тектонические $-1=1$ нарушения (арабские цифры), зоны надвигов: 1 - Нестеров…ㅍ.:…: 2 ская, 2 - Бутынь-Хлевчанская, 3 - Белз-Милятинская; сбро-

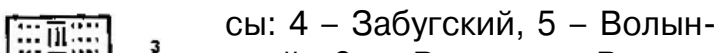
ский, 6 - Владимир-Волын-.- ский (Северный); 7 - границы геолого-промышленных и угленосных районов; шахты: 8 действующие, 9 - строящиеся; 10 - резервные участки для строительства шахт; 11 угольные месторождения (арабские цифры в кружках): 1 - Волынское, 2 - Забугское, 3 - Межреченское, 4 - Тягловское, 5 - Любельское; поля шахт: 10 HВ - № 10 Нововолынская, 3 ЧГ - № 3 Червоноградская, 4 ЧГ - № 4 Червоноградская, 1 ТГ - № 1 Тягловская, 1 ЛБ - № 1 Любельская, (1) 12 лБ - № 2 Любельская

1. Караваев В.Я. Горно-геологические условия разработки // Львовско-Волынский каменноугольный бассейн. - Наук. думка, Киев: 1984. - С. 175-207.

2. Степаненко Я.Г. Особенности состава и строения ме- зозойских отложений Юго-Западного района Львовско-Волынского бассейна и их влияние на разработку угольных месторождений // Доп. НАН Украины. 1999. - № 1. - C. 138-142.

1 The State Geological Enterprise Zakhidukrgeological, Lviv, Ukraine

1 Производственное объединение Запукргеология, г. Львов, Украина

2 Institute of Geological Sciences NAS Ukraine, Kyiv, Ukraine

2 Институт геологических наук НАН Украины, г. Киев, Украина 